\title{
Adolescent Knowledge of Anemia
}

\author{
Yuliaji Siswanto $^{1}$, Faridah Aini ${ }^{2}$, Raharjo Apriyatmoko ${ }^{3}$ \\ \{yuliaji2000@gmail.com¹, farida.aini20@gmail.com² ${ }^{2}$,raharjoapriyatmoko@gmail.com ${ }^{3}$ \} \\ Public Health Study Program, Faculty of Health, Ngudi Waluyo University ${ }^{1}$, \\ Nursing Study Program, Faculty of Health, Ngudi Waluyo University2,3
}

\begin{abstract}
Adolescent girls are the population group most vulnerable to anemia for various reasons. The purpose of study is to describe the level of knowledge of adolescents about anemia. The study used a cross sectional approach with a sample of 100 high school teenage girls who were taken by purposive method. Data collection was carried out using a closed questionnaire. The results showed that knowledge about anemia was mostly in the fairly good category (59.0\%), followed by good knowledge (33.0\%), and poor knowledge (8.0\%). Most of the respondents did not understand the meaning, consequences, impact of anemia, and how to take blood booster tablets. There needs to be an effort to increase the knowledge of young women about anemia to prevent anemia.
\end{abstract}

Keywords: knowledge, anemia, adolescent girls.

\section{Introduction}

Anemia is one of the most common global nutritional problems and difficult to be managed, affecting both developing and developed countries with major consequences for human health and social and economic development. In all ASEAN member countries, except Thailand, more than $25 \%$ of female adolescents were anemic; in some countries the prevalence was 50\% (WHO, 2011) [1]. The research in Nepal in 2014 found the incidence of anemia in female adolescents was $33.33 \%$ [2]. The types and causes of anemia vary widely, but the most common is iron deficiency anemia, which is anemia caused by iron deficiency. Iron deficiency anemia occurs at all stages of the life cycle, but is more common in pregnant women and children. Adolescents, especially women, are very vulnerable to iron deficiency [1],[3].

Adolescence is defined by the WHO as a period of life that includes ages between 10 and 19 years. Adolescents are at high risk of iron deficiency anemia because of the accelerated increase in demand, poor food intake, high infection rates, and worm infestations as well as the consequences of social norms from early marriage and teenage pregnancy.[1] Iron requirements peak during adolescence due to rapid growth, body weight, blood volume, and red blood cell mass, resulting in increased iron requirements for muscle myoglobulin and hemoglobin in the blood. Whereas in female adolescents the occurrence of menstruation is added. Middle adolescent growth occurs between the ages of 12 - 15 years for girls and 1 to 2 years later for boys (between 13 - 16 years of age) [4], [5]. 
The high prevalence of anemia among adolescents if not handled properly will continue into adulthood. Iron deficiency anemia in female adolescents greatly contributes to maternal mortality, premature babies, low birth weight babies and stunted babies [6]. Iron nutrient anemia in rematriates greatly contributes to maternal mortality, premature births, low birth weight (LBW) and stunted babies. This incident is due to rematism at puberty a lot of iron loss during menstruation and is exacerbated by a lack of iron intake. During pregnancy, the need for iron increases threefold for the formation of the placenta and fetal growth. Serious countermeasures need to be done because the various effects of anemia can reduce the quality of human resources, especially in the first thousand days of life.[6]In female adolescents and women of childbearing age, iron deficiency anemia is still a public health problem if the prevalence is $\geq 20 \%$. The Results of Basic Health Research stated that the incidence of anemia in female adolescent in 2007 was $6.9 \%$, to $31 \%$ in 2011, and 22.7\% in 2013 [7]. This shows that iron deficiency anemia in female adolescents has increased and still become a health problem in Indonesia.

The incidence of anemia in Central Java in 2013 reached $57.1 \%$. The results of the study, which took 120 senior high school students in Purwokerto as the samples, found $92.9 \%$ of urban adolescents and 76\% of rural girls suffer from anemia.[8] Research conducted on 109 female students from 3 high schools in Semarang Regency found that $61.5 \%$ of students had anemia [9].

In general, the high prevalence of iron nutrition anemia in adolescents can be caused by three factors, namely: inadequate iron intake, increased physiological needs, and loss of a lot of blood. Another cause is a combination of iron deficiency with other conditions such as socio-economic status [10]. Other factors that indirectly influence the incidence of anemia in adolescents are the mother's education and the adolescent's knowledge. Knowledge or cognitive is a domain that is very influential on a person's actions or behavior [11]. Health education will be an effective method to improve adolescents health through increasing knowledge and changing their attitudes [12]. This study aims to describe the knowledge level of adolescents about anemia.

\section{Method}

The design used in this study was descriptive with a cross sectional approach. The population in this study were all adolescents registered in Senior High Schools in Semarang Regency in the even semester of 2018/2019 as many as 30,230 students. The samples were taken purposively from SMAN 2 Ungaran, SMAN 1 Bergas, and SMA Muhammadiyah Sumowono as many as 100 female students. The consideration to choose research locations was to represent rural, semi-urban and urban areas. Data collection was carried out using a closed questionnaire. SPSS version 20 was used to analyze data descriptively. The level of knowledge is good if the correct number is $>75 \%$ (score $>27$ ), sufficient if the correct number is $56 \%-75 \%$ (score 20-27), and poor if the correct number is $<56 \%$ (score $<12$ ). This research has passed ethics from the Health Research Ethics Commission (KEPK), Faculty of Sport Sciences, Semarang State University (Ethical Clearance) Number: 188 / KEPK. 


\section{Result}

In Table 1, it can be seen that the age of the respondents is almost similar, there were 46 respondents $(46.0 \%)$ at the age of 16 , and 44 respondents $(44.0 \%)$ at the age of 15 . The results of measuring knowledge by using a questionnaire consisting of 12 questions obtained a mean score (middle value) of 27.00 with the lowest score of 9 and the highest score of 31.

Table 1. The Description of respondents' age

\begin{tabular}{ccc}
\hline Age (year) & $\mathrm{f}$ & $\%$ \\
\hline 14 & 3 & 3,0 \\
15 & 44 & 44,0 \\
16 & 46 & 46,0 \\
17 & 6 & 6,0 \\
18 & 0 & 0,0 \\
19 & 1 & 1,0 \\
\hline Total & 100 & 100,0 \\
\hline
\end{tabular}

Table 2 The description of knowledge level on anemia

\begin{tabular}{lcc}
\hline \multicolumn{1}{c}{ Knowledge Level } & Frequency & Percentage \\
\hline Good & 33 & 33,0 \\
Sufficient & 59 & 59 \\
Poor & 8 & 8,0 \\
\hline Jumlah & 100 & 100,0 \\
\hline
\end{tabular}

Table 2 shows that the highest percentage was respondents with sufficient knowledge of anemia, namely $59.0 \%$, followed by good knowledge of $33.0 \%$, and there were still $8 \%$ of respondents with poor knowledge. 


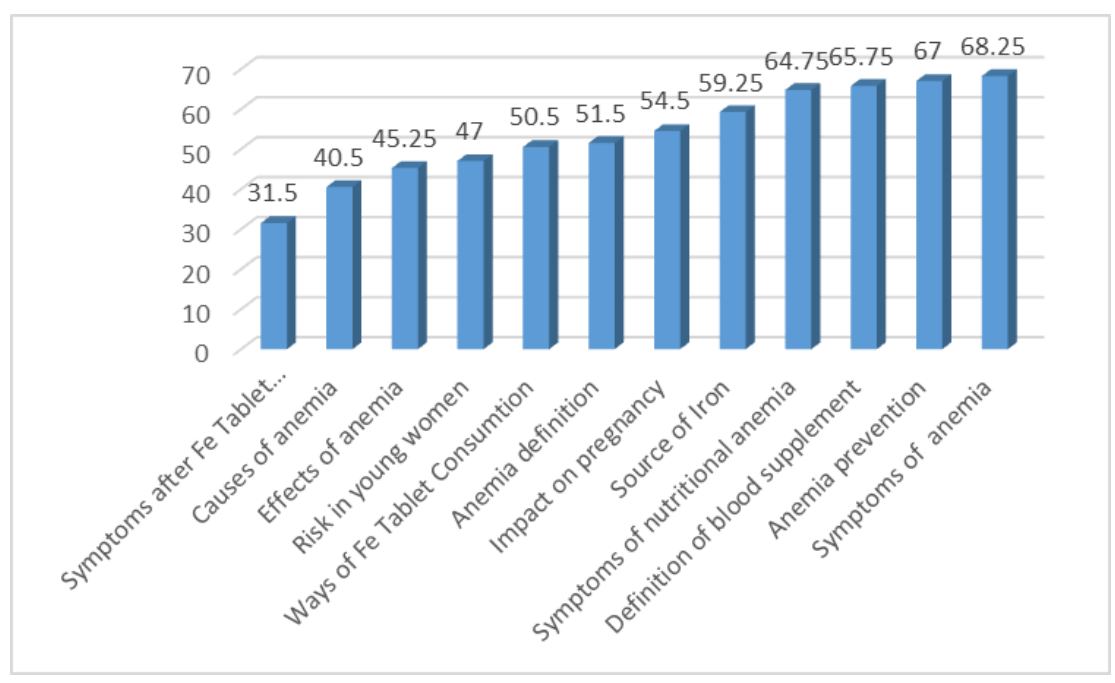

Grafik 1 The mean of knowledge dimentions

\section{Discussion}

This study find that $59.0 \%$ of respondents have sufficient knowledge level, while $33.0 \%$ of respondents have good knowledge level, and there were still $8 \%$ of respondents with poor knowledge level. Poor knowledge of female adolescents about anemia can be caused by insufficient information about anemia. A person's understanding is obtained through knowledge which is the result of knowing and this occurs after people sense a certain object. Sensing occurs through the human senses, namely the senses of sight, hearing, smell, taste and touch. Most of human knowledge is obtained through the eyes and ears. Knowledge will underlie beliefs about an object and will form a habit, this is what will then bring out the desire that is raised in attitudes and behavior [11].

The measured knowledge is the knowledge that the respondent has about anemia which includes 6 indicators and 12 question items. The question items that many respondents know about are indicators of anemia symptoms and how to prevent anemia. Meanwhile, the question items that were fairly and less known by the respondents were indicators of understanding anemia, causes of anemia, due to anemia, and consumption of blood supplement tablets. This can be caused by a lack of complete information about anemia. Young women should gain knowledge about anemia through health education in schools, the mass media, or through counseling in health facilities. Based on information from respondents, they have received blood booster tablets from health workers who came to school, but they did not receive complete information about anemia.

The causes of iron deficiency anemia are chronic blood loss, insufficient iron intake and inadequate absorption and an increased need for iron to form red blood cells, which commonly occurs during infancy, puberty, pregnancy and breastfeeding. On male adult, most of the blood loss is caused by the bleeding process due to disease (trauma), or due to treatment of a disease, while on women occur because of natural blood loss every month [13]. 
Some people, after consuming iron tablets, can feel symptoms such as nausea, vomiting, pain in the stomach area, sometimes diarrhea and even difficulty passing stool [14]. For teenagers who do not know, they will immediately stop consuming blood booster tablet. It is reccomended that iron tablets are taken at night to avoid the symptoms mentioned above. It is better if the consumption of iron tablets is not at the same time as consuming food and drugs such as; milk, tea, coffee and heartburn medicine. Milk has a high calcium content which reduces the absorption of iron in the intestinal mucosa. Coffee and tea contain caffeine and tannins which can bind iron into complex compounds so that iron cannot be absorbed. While ulcer medication serves to coat the surface of the stomach, this can inhibit iron absorption.

The older a person is, the more mature his mindset will be and the better his knowledge will be [15]. Therefore age can affect a person's knowledge because the older a person is, the better his mindset will be so that he is better at responding to an object or problem. The increasing age of a person can affect the knowledge he / she gets, but at certain ages or before elderly age the ability to accept or remember a knowledge will decrease. Experience is a source of knowledge, or experience is a way to obtain the truth of knowledge. Personal experience can be used as an effort to obtain something. Adolescents according to WHO (2013) are the population in the age range 10-19 years. Based on the results of the study, it can be seen that the age of the most respondents is 16 years old with 46 respondents (46.0\%) and 44 respondents (44.0\%) with an average age of respondents 15.59 years.

The results of this study are almost the same as several previous studies. Research on young women in New Delhi, India in 2015 found that the majority of respondents (64\%) had average knowledge (sufficient), 36\% of respondents had a good level of knowledge, and none of them had a low level of knowledge [16]. Research conducted on high school students in Medan shows that the majority of female adolescent knowledge about iron deficiency anemia is in the sufficient knowledge category, 73 respondents (77.7\%), good category 18 respondents (19.1\%), and poor category 3 respondents (3.2\%).[17] Furthermore, research on female students at SMA Negeri 1 Talang Padang found that the knowledge level of young women about anemia was less $53.1 \%$ and $46.9 \%$ sufficient [18].

The results of this study are slightly different from the research conducted in India which showed that most of the girls $(57.0 \%)$ had insufficient knowledge, only $43.0 \%$ had sufficient knowledge, and none had a good level of knowledge.[19] Research conducted on students of SMKN Tepus, Gunung Kidul, DIY in 2019/2020 also found different results from this study, namely 39 respondents (50.6\%) had a good level of knowledge, and as many as 38 respondents $(49.4 \%)$ have a sufficient level of knowledge.[20] Furthermore, the results of this study are also different from previous research conducted in 2015 which took samples in 3 high schools in Semarang Regency, namely SMAN 2 Ungaran, SMAN 1 Ambarawa, and SMAN 1 Suruh, which obtained the results of most respondents $2 \%$ ) have a good level of knowledge of anemia.[9] This difference can be caused by the objectives, timing of implementation, and the instruments used.

\section{Conclussion}

The knowledge of female adolescents about anemia is mostly in the sufficient category, namely 59\%. To prevent anemia in adolescents, it is important to carry out 
health education for adolescents about anemia in a complete manner using interactive information media

\section{References}

[1] World Health Organization, "Prevention of iron deficiency anaemia in adolescents," Role Wkly. Iron Folic Acid Supl., p. 50, 2011.

[2] N. Limbu, D. Thakur, B. K. L. Das, L. B. Choudhary, A. Pradhan, and D. Baral, "Prevalence of anemia and iron deficiency in adolescent school girls of Dharan, Nepal," Asian J. Med. Sci., vol. 8, no. 5, pp. 22-26, 2017, doi: 10.3126/ajms.v8i5.17546.

[3] Kemenkes RI, "Pedoman Penanggulangan Anemia Gizi Untuk Remaja Putri Dan Wanita Usia Subur," Direktorat Jendral Kesehat. Masy., pp. 1-16, 2019.

[4] J. L. Beard, "Symposium: Improving Adolescent Iron Status before Childbearing Iron Requirements in Adolescent Females," J. Nutr., vol. 22, pp. 440-442, 2000.

[5] N. Deshpande, D. Karva, S. Agarkhedkar, and S. Deshpande, "Prevalence of anemia in adolescent girls and its co-relation with demographic factors," Int. J. Med. Public Heal., vol. 3, no. 4, p. 235, 2013, doi: 10.4103/2230-8598.123426.

[6] Kemenkes RI, Profil Kesehatan Indonesia 2017. Jakarta: Kementerian Kesehatan Republik Indonesia, 2017.

[7] Kemenkes, Riset Kesehatan Dasar (Riskesdas) Tahun 2013," Jakarta: Kemenkes RI, 2013.

[8] D. Sari, "Anemia Gizi Besi pada Remaja Putri di Wilayah Kabupaten Banyumas," J. Kesmas Indones., vol. 8, no. 1, pp. 16-31, 2016, [Online]. Available: http://jos.unsoed.ac.id/index.php/kesmasindo/article/view/138/127.

[9] Y. Siswanto and S. Widyawati, Kajian Anemia Pada Siswi SMA Di Kabupaten Semarang. Magelang, Jawa Tengah, 2016.

[10] Departemen Gizi dan Kesehatan Masyarakat, Gizi dan Kesehatan Masyarakat, Edisi Revi. Jakarta: Rajawali Press, 2011.

[11] Notoatmojo, S., Promosi Kesehatan dan Perilaku Kesehatan. Jakarta: PT. Rineka Cipta, 2012.

[12] A. D. and B. P. Lina Bandyopadhyay, Muktisadhan Maiti, "Intervention for improvement of knowledge on anemia prevention: A school-based study in a rural area of West Bengal," Int. J. Heal. Allied Sci., vol. 6, no. 2, p. 69, 2017.

[13] M. Arisman, Gizi Dalam Daur Kehidupan, Cetakan Ke. Jakarta: EGC, 2010.

[14] Profil Kesehatan Indonesia Tahun 2015. Jakarta: Kementerian Kesehatan Republik Indonesia, 2015.

[15] M. Wawan, A., \& Dewi, Teori Dan Pengukuran Pengetahuan Sikap Dan Perilaku Manusia. Yogyakarta: Nuha Medika, 2011.

[16] S. Ahwal, "A Study to Assess the Knowledge and Prevalence of Iron Deficiency Anemia among Adolescent Girls in a Selected College of New Delhi," Int. J. Nurs. Pr., vol. 6, no. 3, pp. 9-13, 2019.

[17] S. D. Sihotang and N. Febriany, "Pengetahuan dan Sikap Remaja Puteri Tentang Anemia Defisiensi Besi di SMA Negeri 15 Medan," pp. 40-45, 2010.

[18] S. Laksmita and H. Yenie, "Hubungan Pengetahuan Remaja Putri Tentang Anemia dengan Kejadian Anemia di Kabupaten,” J. Ilm. Keperawatan Sai Betik, vol. 14, no. 1, p. 104, 2018, doi: 10.26630/jkep.v14i1.1016.

[19] S. Gracy and J. S. N, "Original Research Paper Management Knowledge Regarding Prevention and Management of Anemia Among Adolescent Girls . Gracy S N . Junior Sundresh,” vol. VI, no. VII, 2017.

[20] R. C. M. Ika Mustika Dewi, Prastiwi Putri Basuki, "Hubungan tingkat pengetahuan tentang anemia dengan kejadian anemia pada remaja putri," J. Ilm. STIKES Kendal, vol. 10, no. 4, pp. 589-598, 2020. 